\title{
Policies for Promotion of Electric Vehicles and Factors Influencing Consumers' Purchasing Decisions of Low Emission Vehicles
}

\author{
Matjaz Knez ${ }^{1}$, Matevz Obrecht ${ }^{* 2}$ \\ ${ }^{1}$ Faculty of Logistics, University of Maribor, Mariborska 7, 3000 Celje, Slovenia \\ e-mail: matjaz.knez@um.si \\ ${ }^{2}$ Faculty of Logistics, University of Maribor, Mariborska 7, 3000 Celje, Slovenia \\ e-mail: matevz.obrecht@um.si
}

Cite as: Knez, M., Obrecht, M., Policies for Promotion of Electric Vehicles and Factors Influencing Consumers' Purchasing Decisions of Low Emission Vehicles, J. sustain. dev. energy water environ. syst., 5(2), pp 151-162, 2017, DOI: http://dx.doi.org/10.13044/j.sdewes.d5.0139

\begin{abstract}
Recently different studies of green transport have become interesting for policy makers, car manufacturers, customers and energy suppliers. Many stakeholders from the public and private sectors are investing a lot of effort to identify consumer behaviour for future improvements in development of green products and effective strategies, which could accelerate the transition to sustainable future. This paper presents the effects of electric vehicle promotional policies and customer preferences about alternative fuel vehicles. This study has shown that the electric vehicle promotional policies adopted in Slovenia have been unsuccessful, as the share of first-time registered electric vehicles in 2013 was below $1 \%$. For different segments of people whose opinions about low emission vehicles differ, different measures must be adopted. When designing promotional policies focus must be on the most relevant factors such as the total vehicle price and fuel economy.
\end{abstract}

\section{KEYWORDS}

Low emission vehicles, Electric vehicles, Slovenia, Promotional policies, Purchasing behaviour, Consumer segmentation.

\section{INTRODUCTION}

Since the oil crises in 1970s, various countries have already adopted preliminary plans for Electric Vehicle (EV) promotion, with the intention of eventually replacing internal combustion engine vehicles, as their exhaust causes significant environmental pollution [1]. This research includes battery electric vehicles, hybrid vehicles (and plug-in hybrids) and fuel cell vehicles (electric vehicles). Countries such as Japan and the United States of America (USA) have managed to increase electric vehicle sales, with the help of effective policies promoting their use. The European Union (EU) and other European countries have followed these trends and put into place their own electric vehicle promotional policies, which in some countries, in particular the EU Member States, have been subject to continual improvement.

Electric vehicle promotional policies can be divided geographically, according to their adoption on the international, national or local level [2]. Policies can also be divided

\footnotetext{
${ }^{*}$ Corresponding author
} 
from the legislative perspective into internationally binding and non-binding policies. They can include fiscal and non-fiscal incentives, which encompass a wide range of incentives and measures [3]. From the customer's or consumer's perspective, these measures can be divided into direct or indirect measures. The use of electric vehicles can be promoted among potential buyers with direct measures, while the development of electric vehicles can be stimulated with indirect measures in order to meet the customer or even the legislative body's needs. Policies can be accepted unilaterally [4] or as an agreement between representatives of the society [5]. The availability of alternative energy sources and the environmental impact of transportation sector will play major role in the evolution of the transportation sector. Limited oil reserves especially in the EU and consequently political and economic risks can be seen as the most important drivers to reduce fossil fuel dependency and develop alternative solutions. To reduce fossil fuel dependency and transport related environmental impacts effective policy measures such as reduced use of personal transportation, promotion of cycling, walking and public transport must be developed and implemented [6]. However, because of current life style, western standard of living and related independence of traveling with personal vehicle [7] promotion of environmentally sound alternatives such as Low Emission Vehicles (LEV) (vehicles on LPG, CNG, biofuels, electric vehicles and hybrids) is crucial [8] as well as smart grid implementation and reduction of peak energy use. This can be done with charging electric vehicles during the night as well as by heating houses at night as proposed by Babak et al. [9].

In order to solve the challenges posed by the various Alternative Fuel Vehicles (AFV) promotional policies, similar international electric vehicle policies must be studied, analysed and cross-compared individually to evaluate their efficiency and to enable high transport eco-efficiency described by Moriarty and Wang [10] as maximising benefits to society while minimising transport related environmental impacts.

This study reveals that there is no review of the effects of the various policy measures for the promotion of electric vehicles in Slovenia. The purpose of this paper is therefore to consider the content and effects of these policies with special emphasis on Slovenian policies for promotion of LEV as well as their evolution from the decision-making stage and on the end point out some financial and non-financial factors which influence the demand of LEV. In this respect unveiling previous policy measures, evaluate its effects and success in comparison with other studied countries as well as revealing the consumers' preferences is necessary for effective future policy measures and for promotion and commercialisation of LEV and AFV.

\section{METHODS}

In order to analyse the various international electric vehicles promotional policies, special data were collected from a range of publications produced by international organizations, such as the International Energy Agency (IEA) and national statistical databases, as well scientific and professional papers from the Emerald Insight, ProQuest Social Science Journals and ScienceDirect databases. Compilation method was used to gather and study the data on electric vehicle promotional policies in Slovenia and abroad. For the study of Slovenian electric vehicle promotional policies and statistics, publications (annual reports, appeals, etc.) and internal information from Eco Fund (interviews with Eco-fund middle management) were also used to gather all required data. Data included in annual reports were synthesised to present the general situation in Slovenia. Individual project reports related to electric vehicles in Slovenia as well as national statistical data were also used.

All gathered data has been analysed to make a concise review of electric vehicle policy in Slovenia and to study how many electric vehicles were registered for the first 
time per year in Slovenia and compared with promotional measures used at that time. The number of registered electric vehicles in Slovenia was then cross-compared with the number of first registrations of electric vehicles on annual basis from Austria, Germany and Great Britain to evaluate the efficiency of policies and development of electric vehicle market in Slovenia compared to three other studied countries. The share of electric vehicles (out of all vehicles) was used as a basis for the comparative analyses.

As Cowan and Hultén [1] claim, it was after the oil crisis in 1970s that the first policies for promoting the use of electric vehicles came into force. However the focus of this review of electric vehicle promotional policies in Slovenia is after 1991, the year in which Slovenia became independent. All electric vehicles registered by March 2014 were included in this research.

In the second part of the paper consumer preferences (crucial factors for purchasing LEV) and segmentation of consumers data obtained by the pre-structured questionnaire from Borthwick and Carreno [11] modified and distributed in Slovenia were used to indicate that promotional policies must focus on the most susceptible segments of consumers to be the most successful [8]. It must also address only relevant financial and non-financial factors because differences can occur in importance of factors in different geographical or cultural areas; therefore relevant financial and non-financial factors for Slovenian consumers were studied.

\section{REVIEW OF POLICIES FOR PROMOTING THE USE OF LEV IN SLOVENIA}

The accession of Slovenia to the EU and the signing of the international agreement on environmental goals (Kyoto Protocol) constitute the starting point of policies for the promotion of electric vehicles in Slovenia [12]. Slovenia's accession to the EU in particular is an important milestone, as with this act, Slovenia chose to respect the developmental guidelines on electric vehicles already in place in the EU. Slovenia has modified its legislation by transferring important regulations directly or indirectly connected with the area of electric vehicles promotion into her legislation [13].

In 2005, the Slovenian Hydrogen and Fuel Cell Technology Platform (SIHFC) was established by the Chamber of Commerce and Industry alongside the relevant ministry. The SIHFC organized the first event, where the technology of electric vehicles, electric vehicles made by car manufacturers (cars that could actually be bought at that time) and electric vehicles converted by individuals were presented to the public [14]. In January 2012 the first fast charging station for battery electric vehicles was opened in Maribor [15]. With the introduction of charging points, there has been an increase in the use of battery electric vehicles, which are mainly used by electricity distribution companies for promotional activities [16]. At present, there are over 206 charging points for electric vehicles in Slovenia [17] and even though Slovenia has a leading position in the EU regarding the number of installed charging points [18], the number of charging points is still much lower than that proposed by the EU Commission, which proposed 3,000 charging stations for Slovenia [19].

Contrary to other types of electric vehicles, hybrid vehicles have already been present on the Slovenian car market for some time, longer than any other type of electric vehicle [11]. The first hybrid vehicles on the market were Toyota Prius [20], followed by Honda Civic Hybrid [21] and Honda Insight [22]. The number of registered hybrids has gradually grown along with the number of car manufacturers offering them and the number of available models. For example, Toyota itself is currently selling six different hybrid vehicles [23]. A small number of customers have accepted the idea of such vehicles, which are becoming more and more competitive in comparison to vehicles with only petrol/diesel engines. Hybrid vehicles owners also pay lower road tax because of their smaller Carbon dioxide $\left(\mathrm{CO}_{2}\right)$ emissions [22]. 
Potential electric vehicle buyers can apply to an Eco Fund for financial subsidies and loan schemes to help with their purchase. The Eco Fund approves loans for electric vehicles if its emissions do not exceed a predetermined level. These loans are intended specifically for hybrid vehicles, as they do not exceed the strict rules governing emissions. Between 2004 and 2012, the Eco Fund approved 146 loans for hybrid vehicles [24]. Since 2011, the general public as well as companies have had the chance to receive financial grants for the purchase of electric vehicles that meet predetermined criteria, or for customizing any vehicle into an electric one in compliance with the relevant criteria [25]. Grants are available only for battery electric vehicles and plug-in hybrid vehicles. Unfortunately, these grants remain rather unexploited [26], as the share of electric vehicles is still relatively low. The Eco Fund also gives grants to transport companies for the conversion of buses to biogas or compressed natural gas. In 2012, there were no applicants, so no grants were approved or given [24].

The question must be asked as to whether the public is properly informed about the possibility of receiving grants to purchase electric vehicles [27]. Moreover, Hackbarth and Madlener [28] revealed that households are willing to pay considerable amounts for greater fuel economy and emission reduction, improved driving range and charging infrastructure, as well as for enjoying vehicle tax exemptions and free parking or bus lane access. However, they are usually insufficiently informed about the public incentives and policies promoting electric vehicles. The possibility of companies receiving grants for electric vehicles can also be very important for their promotion, particularly in large and well-known companies.

Besides the government, which operates electric vehicle promotion policies, local authorities also play a key role, as they are an important partner in international projects, carrying out demonstration projects and adopting goals concerning the introduction of electric vehicles into everyday use [29] as proposed also in Maribor, second largest city in Slovenia [30]. Slovenian capital Ljubljana which is also green capital of Europe 2016 has adopted an electro mobility plan in which there are clearly determined measures to encourage the use of electric vehicles in the city [31]. Car dealers, who represent car manufacturers, often do not take part in policies for promoting the use of electric vehicles. Even when they organise special offers for replacing old vehicles with new, cleaner vehicles [32], a problem arises, as most of the car dealers behind such offers do not sell electric vehicles [33].

Past and present electric vehicle promotion policies were adopted as a result of cooperation between public and private institutions e.g., research institutes and car industry representatives. For this purpose, electric vehicle development strategies were drawn-up, financial grant schemes were accepted alongside with other measures and activities. Review of these measures and activities is presented in Table 1.

Additionally, international project cooperation between the public and private sector was also established on this basis. These projects were mainly focused in research and development and cooperation of different EU Member States with private sector such as:

- MAG-DRIVE project (2010-2016) - with its emphasis on producing novel or substantially improved materials for permanent magnets, replacing or greatly reducing the rare-earth content, which will result in weight reductions and power density increases, making the magnets more suitable for recycling and dismantling, and leading to increased efficiency when integrated into automotive systems [34];

- SMART V2G project (2011-2014) - with the main objective connecting the electric vehicle to the grid by enabling controlled flow of energy and power through safe, secure, energy efficient and convenient transfer of electricity and data [35]; 
- EUROLIION project (2011-2015) - with the main objective developing a new Liion cell for traction purposes with the following characteristics: 'High energy density of at least $200 \mathrm{Wh} / \mathrm{kg}$ ', 'Low costs i.e., a maximum of $150 \mathrm{EUR} / \mathrm{kWh}$ ' 'Improved safety'. Although the Li-ion cell appears to be the most appropriate technology to meet these goals, considerable research and development is required [36];

- CAPIRE project (2010-2014) - focused on the definition of the potential Flagships projects which could foster the competitiveness of the European Automotive Industry in the domain of Transport Electrification as well as in the development of technologies and services to reduce the European $\mathrm{CO}_{2}$ footprint [37];

- HYSYS project (2005-2009) - focused on the research on of low-cost components for Fuel Cell (FC-) systems and electric drive systems which can be used in future hybridised FC-vehicles (medium term objective) and ICE vehicles [38].

While the participating partners have defended the success of these activities, the real effects are seen through electric vehicle sales, which have not met the predictions made by car sales companies [39].

Table 1. Presentation of activities and measures for promoting the use of electric vehicles in Slovenia

\begin{tabular}{|c|c|c|c|c|}
\hline $\begin{array}{l}\text { Activity/measure } \\
\text { and its time span }\end{array}$ & Description & $\begin{array}{l}\text { Type of included } \\
\text { electric vehicle }\end{array}$ & $\begin{array}{l}\text { Competent } \\
\text { authority }\end{array}$ & Interesting details \\
\hline $\begin{array}{c}\text { Loan scheme } \\
\text { (available since 2004) } \\
{[24,40]}\end{array}$ & $\begin{array}{l}\text { Citizens and legal entities } \\
\text { can ask for a loan to buy } \\
\text { electric vehicle, which price } \\
\text { does not exceed } \\
40,000 \text { EUR }\end{array}$ & $\begin{array}{c}\text { Hybrid vehicles, } \\
\text { battery electric } \\
\text { vehicles } \\
\text { (since 2009) }\end{array}$ & $\begin{array}{l}\text { Eco Fund of the } \\
\text { Republic of } \\
\text { Slovenia }\end{array}$ & $\begin{array}{l}\text { In } 2009 \text { a new criteria for } \\
\text { approving loans came } \\
\text { into force: } \mathrm{CO}_{2} \text { levels of } \\
\text { electric vehicles cannot } \\
\text { exceed } 120 \mathrm{~g} / \mathrm{km} \\
\text { (from } 2010110 \mathrm{~g} / \mathrm{km} \text { ) }\end{array}$ \\
\hline $\begin{array}{c}\text { Promotional event } \\
\text { CEVELJ (2007-2010, } \\
\text { 2012-2013, } \\
\text { annual events) [14] }\end{array}$ & $\begin{array}{l}\text { Public was acquainted with } \\
\text { electric vehicles (electric } \\
\text { vehicles made by car } \\
\text { manufacturers) and electric } \\
\text { vehicles converted by } \\
\text { individuals }\end{array}$ & $\begin{array}{c}\text { All electric } \\
\text { vehicles on the } \\
\text { market }\end{array}$ & $\begin{array}{c}\text { Various } \\
\text { organizations }\end{array}$ & $\begin{array}{c}\text { In } 2010 \text { event changed its } \\
\text { name from CEVELJ into } \\
\text { ECOmeet }\end{array}$ \\
\hline $\begin{array}{l}\text { Taxation of vehicles } \\
\text { (adopted in 2009, came } \\
\text { into force in 2010) [41- } \\
44]\end{array}$ & $\begin{array}{l}\text { Tax rate of vehicles } \\
\text { depends on } \mathrm{CO}_{2} \text { emissions } \\
\text { (the higher the } \mathrm{CO}_{2} \\
\text { emissions are, higher the } \\
\text { tax rate is); Tax rates are } \\
\text { also dependent on the type } \\
\text { of internal combustion }\end{array}$ & $\begin{array}{c}\text { All electric } \\
\text { vehicles on the } \\
\text { market }\end{array}$ & $\begin{array}{c}\text { Financial } \\
\text { Administration } \\
\text { of the Republic } \\
\text { of Slovenia }\end{array}$ & $\begin{array}{c}\text { The lowest tax rate is } \\
0.5 \% \text { for petrol or } \mathrm{LPG} \\
\text { vehicles with } \mathrm{CO}_{2} \\
110 \mathrm{~g} / \mathrm{km} \text { and the highest } \\
\text { tax rate is } 31 \% \text { for diesel } \\
\text { vehicles with } \mathrm{CO}_{2}+ \\
250 \mathrm{~g} / \mathrm{km}\end{array}$ \\
\hline $\begin{array}{c}\text { Financial subsidies } \\
\text { (available since 2011) } \\
{[24,40]}\end{array}$ & $\begin{array}{l}\text { Citizens and legal entities } \\
\text { can ask for a financial } \\
\text { subsidy for EV; Total sum } \\
\text { of money for financial } \\
\text { subsidies is 500,000 EUR } \\
\text { per year; Subsidies depend } \\
\text { on type and class of the } \\
\text { vehicle; The lowest is } \\
1,000 \text { EUR and the highest } \\
\text { is 5,000 EUR; In } 2016 \\
\text { financial subsidy for battery } \\
\text { electric vehicle is raised on } \\
7,500 \text { EUR, for plug-in } \\
\text { 3,500 EUR and for } \\
\text { converted up to 5,000 EUR }\end{array}$ & $\begin{array}{l}\text { Battery electric } \\
\text { vehicles, plug-in } \\
\text { hybrid vehicles }\end{array}$ & $\begin{array}{l}\text { Eco Fund of the } \\
\text { Republic of } \\
\text { Slovenia }\end{array}$ & $\begin{array}{l}\text { Until } 2014 \text { price of } \\
\text { electric vehicle had to be } \\
\text { under 50,000 EUR (VAT } \\
\text { included) if citizens or } \\
\text { legal entities wanted to } \\
\text { receive financial subsidy; } \\
\text { In } 2014 \text { there has been a } \\
\text { slight change in the } \\
\text { amount of financial } \\
\text { subsidies for vehicles } \\
\text { because of the new EU } \\
\text { regulation }\end{array}$ \\
\hline
\end{tabular}




\section{RESULTS AND DISCUSSION}

\section{The effects of electric vehicle promotional policies}

The first electric vehicles, which were actually customized vehicles, were registered for the first time in 1993. However, a growth in the number of electric vehicles registered for the first time has been seen only since 2004. The number of first-time registered electric vehicles in Slovenia is presented in Figure 1. As is evident from the graph, most of the registered electric vehicles are HEV. BEV started to appear in 2011 and there are still no fuel cell vehicles in Slovenia [45].

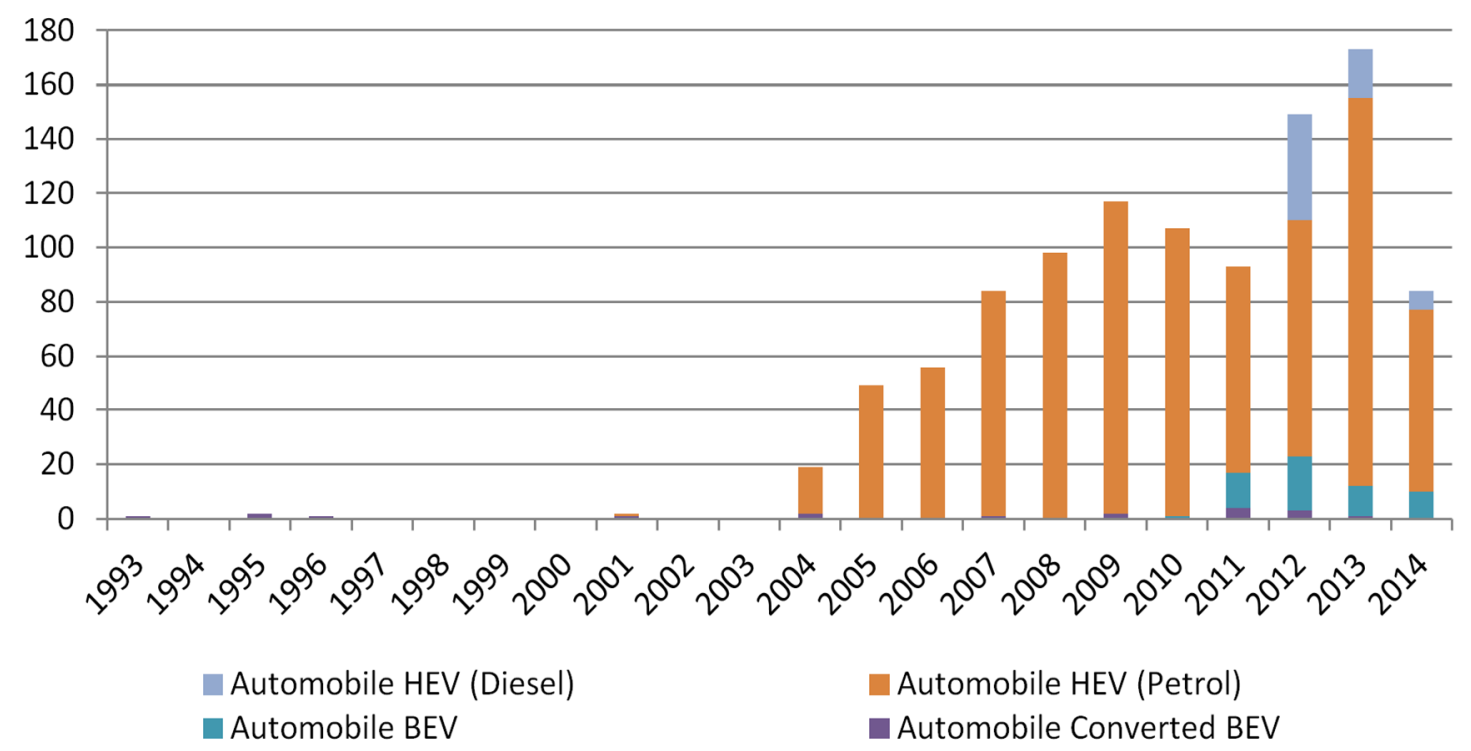

Figure 1. Number of electric vehicles (category: automobiles), registered for the first time in Slovenia (per year) [45-47]

When the share of electric vehicles out of all vehicles registered for the first time in Slovenia, Austria, Germany and Great Britain is compared as presented in Figure 2, significant deviations can be noted.

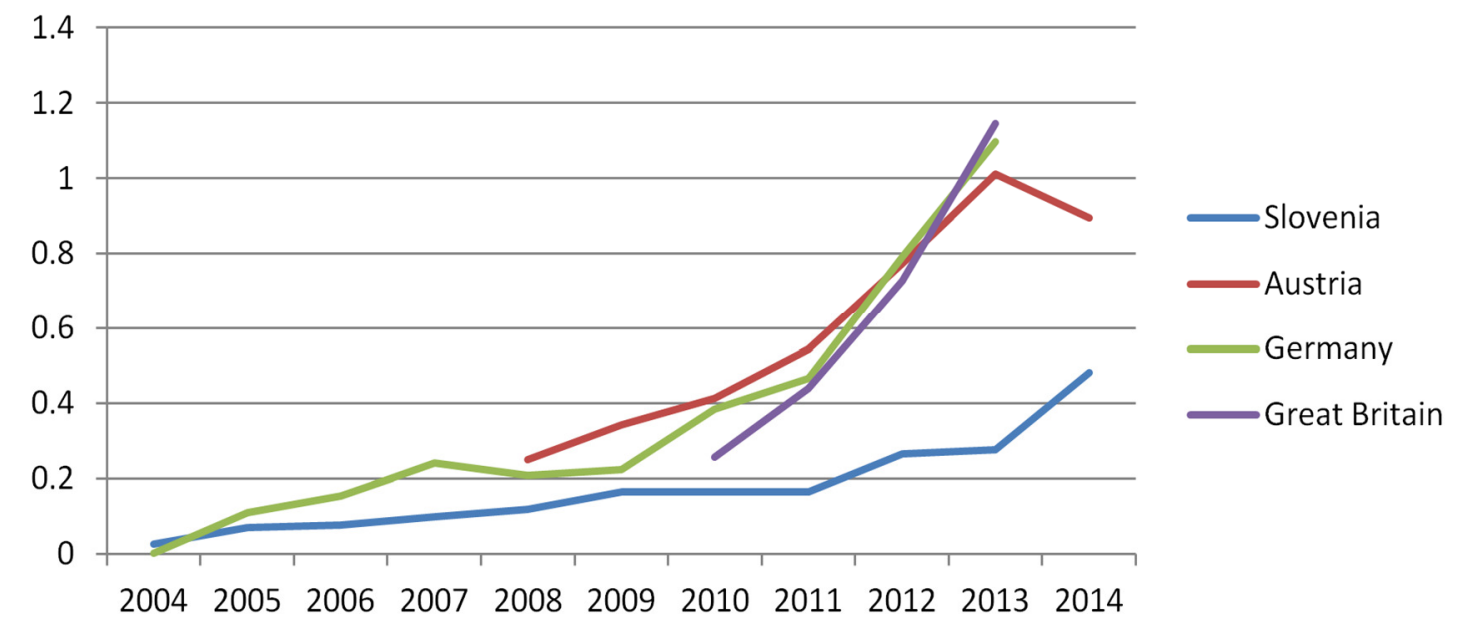

Figure 2. Share of electric vehicles in Slovenia, Austria, Germany and Great Britain (category: automobiles; per year, in \%) [45-51]

The share of electric vehicles in Slovenia per year does not reach the shares of electric vehicles in other countries where electric vehicle promotion policies seems to be 
implemented more efficiently. The share of electric vehicles in 2013 in Austria (1.011\%), Germany (1.098\%) and Great Britain (1.146\%) was more than three times higher than in Slovenia $(0.278 \%)$, which means that Slovenian policy is obviously not motivating enough to increase electric vehicle demand.

This was most probably the reason why subsidies for electric vehicles increased in 2016, there are more charging stations, parking places free of charge for electric vehicles etc., so a combination of new measures seems to be implemented because this seems to be the winning combination also in case of Norway which has the highest share of newly registered electric vehicles.

Additionally measures for promotion and education on electric vehicles should be much more frequent and accessible to bring them closer especially to the public susceptible to LEV. This seems to be the most appropriate measure because the share of potential buyers of electric vehicles is still extremely low due to lack of information on technology, battery range and power performance between the general public.

A vital ingredient to the success of electric vehicle integration is along with policy development also the development of proper infrastructure. This requires additional financing as well as cooperation between different stakeholders, especially retailers, municipalities, electricity providers, land owners, installers as well as consumers. Due to conflict of interests this is sometimes tricky and extremely time consuming. Slovenia is in the EU leading in this perspective since it has wide spread network of public charging stations. However problems arise since the number of charging stations is still insufficient on more frequent locations such as city centres, shopping malls etc., charging stations can be occupied when needed, roaming is not yet fully functional, etc. Collaboration should be improved and should start with clear strategy on Slovenian charging infrastructure that is still missing and could give clear signal to different stakeholders about frequency, dispersion and availability of charging stations.

Another issue that needs to be addressed is also the electricity for charging electric vehicles because huge differences can be expected in environmental feasibility of electric vehicles if charged with renewable or conventional energy sources [52].

\section{Customer preferences and opinions about $\mathrm{LEV}$}

It is essential that policies for promotion of low emission vehicles address customer preferences and habits. Different parts of the world need different approaches. Our previous study [8] revealed that three groups of potential consumers exist in Slovenia and that different financial and non-financial factors must be taken into account when designing LEV promotion policy.

The results in Table 2 indicate which factors the promotional policy should address (most important) and which are not relevant (least important). According to most important financial factors (total vehicle price, fuel economy and maintenance/repair cost) analysis has shown that the total vehicle price is already taken into account because policies for promotion of LEV offer subsidies to lower the total price. However there is a lack of information and promotion on the field of fuel economy and maintenance/repair cost. Most of the public is not aware of operating costs of e.g. electric vehicle and this should be enhanced in promotional policies because it is a highly important customer preference. Even »green oriented « consumers take lower carbon emissions as a bonus rather that the main objective [53]. Even battery as the most expensive component of electric vehicle and its aging affecting battery capacity can significantly affect electric vehicle value and can be relevant factor for decision on buying used electric vehicle [54]. Therefore some car manufacturers offer battery leasing where car owner can change battery if degraded.

Carbon emissions and environmental awareness mostly do not have an influence on car choice [55] except when they are tied to road taxes. When analysing least important 
factors, the conclusion was made that each one offers different methods of payment but this seems to be less important for Slovenian consumers. Situation was on the other hand totally different when analysing customer preferences in other EU Member states. When designing policy measures for promotion of LEV with focus on inappropriate factors, success of such measures is questionable. Maybe promotional policies in Slovenia were not successful enough because of inappropriate focusing and because of lacking customer preferences.

Table 2. Most and least important non-financial and financial factors for consideration in LEV promotional policies

\begin{tabular}{|c|c|c|}
\hline & Three most important non-financial factors & Three most important financial factors \\
\hline 1. & $\begin{array}{l}\text { Overall condition and mileage of vehicle } \\
\text { (if you buy a used car) }\end{array}$ & Total vehicle price \\
\hline 2. & Safety features (e.g., airbags) & Fuel economy \\
\hline 3. & Style/appearance/colour & Maintenance/repair costs \\
\hline & Three least important non-financial factors & Three least important financial factors \\
\hline 1. & Acceleration & Annual road tax \\
\hline 2. & Engine type and power & Trade-in value \\
\hline 3. & Brand name (e.g., Volkswagen) & Methods of payment \\
\hline
\end{tabular}

It is recognised that any population is made up of individuals with varying levels of susceptibility towards changing their behaviour [56]. The taxation and other similar policy measures will therefore vary and needs to be accounted for within customer segmentation [8]. Within the Slovene driver population three distinct segments were identified because their susceptibility to different policy measures differ according to their environmental consciousness, interest in buying LEC and their acceptance of LEV as well as their willingness to pay more for environmentally friendlier vehicle. These segments were No-Greens $(20 \%)$ - group not motivated to buy LEV in the near future, Go-With The Flow-Greens (42\%) - positive about LEVs, but are not planning to buy one and Go-Greens (38\%) - environmentally aware and very interested in buying LEVs [8].

Policies for promotion of LEV must therefore reach especially to the Go-With the Flow Greens which are most susceptible for becoming Go-Greens, interested in buying LEVs. No-Greens represent a segment of population that is not going to buy LEVs in the near future and even if promotional policy tries to affect their preferences it will not be effective. Therefore promotional policies must be strategically designed and its focus and reach must be carefully planned.

\section{CONCLUSIONS}

This research has proved that there is no review of the effects of the various policy measures for the promotion of electric vehicles in Slovenia. Slovenia is at the beginning on the so-called "road" to the implementation of electric vehicles, since Slovenia just started to work on strategy for electric vehicles. Nonetheless that the sales of LEV are increasing and that Slovenia is leading in dispersity of charging stations, per capita LEV market is still underdeveloped in Slovenia.

A review of electric vehicle promotion policies is crucial, as this allows us to efficiently review effects and assess the success of individual policies and pinpoint measures for the wider implementation of electric vehicles to avoid inappropriate measures and to focus new strategy for electric vehicle use in Slovenia on measures such as higher subsidies, wide network of public charging stations, education and promotion 
etc. Based on the number of first-time registered electric vehicles, and its share in comparison with other countries it was confirmed that the policies for promoting the use of electric vehicles in Slovenia have been largely unsuccessful, as the share of electric vehicles, e.g., in 2013, has not even reached $1 \%$ of all vehicles and is significantly lower than the share in Austria, Germany and Great Britain.

Single measures do not exist and promotional policies must be adapted to the consumer preferences. Different measures are effective for different environments and different segments of the public. As indicated, No-Greens are not appropriate to be addressed within promotional policies since they are much less susceptible than Go-With the Flow Greens or already convinced Go-Greens. However, Slovenia must address the relatively high share of Go-Greens as well as Go-With the Flow Greens which are more susceptible to LEV.

\section{REFERENCES}

1. Cowan, R. and Hultén, S., Escaping Lock-in: The Case of the Electric Vehicle, Technological Forecasting and Social Change, Vol. 53, No. 1, pp 61-79, 1996, http://dx.doi.org/10.1016/0040-1625(96)00059-5

2. Nilsson, M., Hillman, K. and Magnusson, T., How do we Govern Sustainable Innovations? Mapping Patterns of Governance for Biofuels and Hybrid-electric Vehicle Technologies, Environmental Innovation and Societal Transitions, Vol. 3, pp 50-66, 2012, http://dx.doi.org/10.1016/j.eist.2012.04.002

3. Steenberghen, T. and Lopez, E., Overcoming Barriers to the Implementation of Alternative Fuels for Road Transport in Europe, Journal of Cleaner Production, Vol. 16, No. 5, pp 577-590, 2008, http://dx.doi.org/10.1016/j.jclepro.2006.12.001

4. Calef, D. and Goble, R., The Allure of Technology: How France and California Promoted Electric and Hybrid Vehicles to Reduce Urban Air Pollution, Policy Sciences, Vol. 40, No. 1, pp 1-34, 2007, http://dx.doi.org/10.1007/s11077-006-9022-

5. Ånman, M., Government Policy and the Development of Electric Vehicles in Japan, Energy Policy, Vol. 34, No. 4, pp 433-443, 2006, http://dx.doi.org/10.1016/j.enpol.2004.06.011

6. Turcksin, L., Mairesse O. and Macharis, C., Private Household Demand for Vehicles on Alternative Fuels and Drive Trains: A Review, European Transport Research Review, Vol. 5, No. 3, pp 149-164, 2013, http://dx.doi.org/10.1007/s12544-013-0095$\mathrm{z}$

7. Anderson, S. and Stradling, S. G., Attitudes to Car use and Modal Shift in Scotland, Report of National Centre for Social Research, Scotland: Scottish Executive Social Research, http://www.scotland.gov.uk/Publications/2004/03/19062/34290, 2004, [Accessed: 20-March-2014]

8. Knez, M., Jereb, B. and Obrecht, M., Factors Influencing the Purchasing Decisions of Low Emission Cars: A Study of Slovenia, Transportation Research Part D: Transport and Environment, Vol. 30, pp 53-61, 2014, http://dx.doi.org/10.1016/j.trd.2014.05.007

9. Babak, T., Khavin, G., Duić, N., Boldyryev, S. and Krajačić, G., Possibility of Heat Pump use in Hot Water Supply Systems, Journal of Sustainable Development of Energy, Water and Environment Systems, Vol. 4, No. 3, pp 203-215, 2016, http://dx.doi.org/10.13044/j.sdewes.2016.04.0017

10. Moriarty, P. and Wang, S., Eco-efficiency Indicator for Urban Transport, Journal of Sustainable Development of Energy, Water and Environment Systems, Vol. 3, No. 2, pp 183-195, 2015, http://dx.doi.org/10.13044/j.sdewes.2015.03.0015

11. Borthwick, S. and Carreno, M., Persuading Scottish Drivers to buy Low Emission Cars? The Potential Role of Green Taxation Measures, Transport Research Institute, 
Edinburgh Napier University, Proceedings of $8^{\text {th }}$ Annual Scottish Transport Applications \& Research Conference, Glasgow, Scotland, 2012.

12. Fale, M., Review of Policies for Promoting the use of Electric Vehicles, Celje: Faculty of Logistics, 2014.

13. European Parliament, Electric Cars (in Slovenian), 2011, http://www.europarl. europa.eu/sides/getDoc.do?pubRef=-//EP//TEXT+TA+P7-TA-20100150+0+DOC+XML+V0//SL, [Accessed: 20-March-2014]

14. Elaphe, Presentation of Recent Events CEVELJ 1, CEVELJ 2 and CEVELJ 3 in 2007, 2008 and 2009 (in Slovenian), 2009, http://ecomeet.si/docs/Program_ prireditve/PredstavitevDogodkovCevelj1in2in3.pdf, [Accessed: 17-March-2014 ]

15. Praper, A., Opening of the First Fast Charging Point for Electric Vehicles (in Slovenian), http://www.avtovizije.com/aktualno/dogodki/4956-otvoritev-prve-hitre -polnilne-postaje-za-elektrina-vozila, [Accessed: 20-March-2014]

16. Avtovizije, New Charging Point for Electric Vehicles in Maribor (in Slovenian), 2014, http://www.avtovizije.com/aktualno/reportaze/4002-nova-elektrina-polnilnapostaja-v-mariboru.html, [Accessed: 20-March-2014]

17. Elektrocrpalke, Slovenian Portal for Searching Charging Points for Electric Vehicles (in Slovenian), 2016, http://www.elektro-crpalke.si/, [Accessed: 20-August-2016]

18. Polni.si, Portal for Searching Charging Points, 2016, http://polni.si/, [Accessed: 20-August-2016]

19. Gregorcic \& Slovenian Press Agency, European Commission: Slovenia should build 3,000 Charging Points for Electric Vehicles by 2020 (in Slovenian), 2013, http://www.siol.net/avtomoto/novice/2013/01/bruselj_slovenija_elektricne_polnilni ce.aspx, [Accessed: 25-March-2016]

20. Crnivec, A., Toyota Prius (in Slovenian), 2008, http://www.siol.net/avtomoto/testi/ avtomobili/2008/04/toyota_prius.aspx, [Accessed: 24-March-2014]

21. Jereb, A., Honda Civic Hybrid (in Slovenian), 2008, http://www.siol.net/avtomoto/ testi/avtomobili/2007/11/honda_civic_hybrid.aspx, [Accessed: 21-March-2014]

22. Merljak, M., Honda Insight (in Slovenian), http://www.siol.net/avtomoto/testi /avtomobili/2009/12/honda_insight.aspx, [Accessed: 14-March-2014]

23. Toyota, Models (in Slovenian), http://www.toyota.si/, [Accessed: 20-March-2014]

24. Eco Fund, Annual Report on Activities and Operations of Eco Fund, Slovenian Environmental Public Fund from 2004 to 2012 (in Slovenian), 2013, http://www.ekosklad.si/pdf/LetnaPorocila/, [Accessed: 17-March-2016]

25. Official Gazette of the Republic of Slovenia, Proclamation Part Public Auctions (in Slovenian), http://www.uradni-list.si/_pdf/2011/Ra/r2011079.pdf, [Accessed: 30-April-2014]

26. Purgar, Z., Ljubljana is overtaking Slovenia in the Area of Electric Mobility (in Slovenian), http://www.delo.si/novice/ljubljana/ljubljana-pri-elektricni-mobilnostiprehiteva-drzavo.html, [Accessed: 25-March-2014]

27. Krause, R. M., Carley, S. R., Lane, B. W. and Graham, J. D., Perception and Reality: Public Knowledge of Plug-in Electric Vehicles in 21 U.S. Cities, Energy Policy, Vol. 63, pp 433-440, 2013, http://dx.doi.org/10.1016/j.enpol.2013.09.018

28. Hackbarth, A. and Madlener, R., Consumer Preferences for Alternative Fuel Vehicles: A Discrete Choice Analysis, Transportation Research Part D: Transport and Environment, Vol. 25, pp 5-17, 2013, http://dx.doi.org/10.1016/j.trd.2013.07.002

29. Civitas Elan, Information about CIVITAS ELAN Project (in Slovenian), 2010, www.ljubljana.si/file/.../6.-elektromobilnost-18-4-13-konna-verzija.pdf, [Accessed: 25-March-2014]

30. Klajnscak, T., Around Maribor with Electric Car (in Slovenian), http://www.zurnal24.si/mnozicna-izposoja-elektricnih-vozil-clanek-228045, [Accessed: 29-March-2014] 
31. Razpotnik, I., Loose, N., Jazbinsek Srsen, A., Simonovic, Z. and Klancar, T., The Plan for Sustainable Mobility - Strategy for Sustainable Mobility in City Municipality of Ljubljana, Ljubljana: City Municipality of Ljubljana, Department of Commercial Activities and Traffic (in Slovenian), 2013.

32. Car Dealership Real, Sales Promotion 1,000,000 Euros for ECO Subsidies (in Slovenian), 2014, http://www.avtohisa-real.si/data/slike/dobra_priloznost/OKT_11/ pogoji_eko_subvencij_oktober.pdf, [Accessed: 17-March-2014]

33. Gregorcic, J., When can we Expect All-electric Renault Cars in Slovenia? (in Slovenian), http://www.siol.net/avtomoto/novice/2013/07/renautl_nissan_ze_ev_ prihod_v_slovenijo.aspx, [Accessed: 25-March-2016]

34. MAG DRIVE, MAG DRIVE - Official Project Web Page, 2015, http://mag-drivefp7.eu/, [Accessed: 13-April- 2015]

35. SMART V2G, SMART V2G - Official Project Web Page, 2015, http://www.smartv2g.eu/, [Accessed: 13-April-2015]

36. EUROLIION, EUROLIION - Official Project Web Page, 2015, http://www.euroliion.eu/project-description/, [Accessed: 13-April-2015]

37. CAPIRE, CAPIRE - Official Project Web Page, http://www.capire.eu/public/, [Accessed: 13-April-2015]

38. HYSYS, HYSYS - Official Project Web Page, http://www.hysys.eu/, [Accessed: 13April-2015]

39. Gregorcic, J., Slovenia Confirmed Subsidies for Purchase of Electric Vehicles (in Slovenian), http://www.siol.net/avtomoto/novice/2011/09/slovenski_trg_elektricnih _vozi.aspx, [Accessed: 17-March-2014]

40. Eco Fund, Appealsfrom 8SUB to 27SUB (in Slovenian), 2014, https://www.ekosklad.si/razpisi, [Accessed: 14-August-2016]

41. AMZS, DMV - Motor Vehicle Tax in 2012 (in Slovenian), 2012, http://www.amzs.si/si/356/98/default.aspx, [Accessed: 1-December-2014]

42. EcoMeet, Programme of the Event (in Slovenian), 2010, http://ecomeet.si/docs/ Program_prireditve/EcoMeetSLO.pdf, [Accessed: 28-August-2014]

43. EcoMeet, after the Event (in Slovenian), 2013, http://ecomeet.si/s1/ECOmeet2013/, [Accessed: 17-June-2014]

44. Government of the Republic of Slovenia, Operational Programme for Reducing Emissions of Greenhouse Gases until 2012 (OP TGP-1) (in Slovenian), 2009, http://www.vlada.si/fileadmin/dokumenti/si/projekti/2009/podnebne/op_toplogredn i_plini2012_1.pdf, [Accessed: 29-March-2014]

45. Portal NIO, First Registered Vehicles in 2012, by Month (in Slovenian), http://nio.gov.si/nio/data/prvic+registrirana+vozila+v+letu+2012+po+mesecih, [Accessed: 17-March-2014]

46. Portal NIO, First Registered Vehicles in 2013, by Month (in Slovenian), http://nio.gov.si/nio/data/prvic+registrirana+vozila+v+letu+2013+po+mesecih, [Accessed: 17-March-2014]

47. Portal NIO, First Registered Vehicles in 2014, by Month (in Slovenian), http://nio.gov.si/nio/data/prvic+registrirana+vozila+v+letu+2014+po+mesecih, [Accessed: 17-March-2014]

48. Statistik Austria, Kraftfahrzeuge-Neuzulassungen, http://www.statistik.at/web_de/ statistiken/verkehr/strasse/kraftfahrzeuge_-_neuzulassungen/index.html, [Accessed: 6-May-2014]

49. Statistical Sata Sets GOV UK, Table VEH0130, https://www.gov.uk/government /statistical-data-sets/veh01-vehicles-registered-for-the-first-time, [Accessed: 6May-2014] 
50. KBA Umwelt, Umwelt - Zeitreiche 2004, http://www.kba.de/cln_031/nn_191064/ DE/Statistik/Fahrzeuge/Neuzulassungen/Umwelt/n__umwelt_z_teil_1.html, [Accessed: 6-May-2014]

51. KBA Umwelt, Umwelt - Zeitreiche 2005 bis 2013, http://www.kba.de/cln_031/ nn_191064/DE/Statistik/Fahrzeuge/Neuzulassungen/Umwelt/n_umwelt_z_teil_ _2.html, [Accessed: 6-May-2014]

52. Koziol, J. and Mendecka, B., Evaluation of Economic, Energy-environmental and Sociological Effects of Substituting Non-renewable Energy with Renewable Energy Sources, Journal of Sustainable Development of Energy, Water and Environment Systems, Vol. 3, No. 4, pp 333-343, 2015, http://dx.doi.org/10.13044/j.sdewes.2015.03.0025

53. Auger, D. J., Groff, M. F., Mohan, G., Longo, S. and Assadian, F., Impact of Battery Ageing on an Electric Vehicle Powertrain Optimisation, Journal of Sustainable Development of Energy, Water and Environment Systems, Vol. 2, No. 4, pp 350-361, 2014, http://dx.doi.org/10.13044/j.sdewes.2014.02.0028

54. Anable, J., Lane, B. and Banks, N., Car Buyer Survey: From 'mpg paradox' to 'mpg mirage' - How Car Purchasers are Missing a Trick when Choosing New and used Cars, 2008, http://www.lowcvp.org.uk/assets/reports/Car_Buyer_Report_2008_ Final_Report.pdf, [Accessed: 8-May-2013]

55. Anable, J., 'Complacent Car Addicts' or 'Aspiring Environmentalists'? Identifying Travel Behaviour Segments using Attitude Theory, Transport Policy, Vol. 12, No. 1, pp 65-78, 2005, http://dx.doi.org/10.1016/j.tranpol.2004.11.004

56. Laroche, M., Bergeron, J. and Barbaro-Forleo, G., Targeting Consumers who are Willing to Pay more for Environmentally Friendly Products, Journal of Consumer Marketing, Vol. 18, No. 6, pp 503-520, 2001, http://dx.doi.org/10.1108/EUM0000000006155 